\title{
UPAYA MENINGKATKAN MINAT BELAJAR FISIKA DENGAN MENGGUNAKAN MODEL PEMBELAJARAN SIKLUS (LEARNING CYCLE "5E") DI SMP NEGERI 1PANYABUNGAN
}

\author{
Darwis $^{1)}$; Rizky Ariaji ${ }^{2)}$ \\ ${ }^{1)}$ Pendidikan Fisika, FKIP Universitas Muhammadiyah Tapanuli Selatan \\ ${ }^{2)}$ Pendidikan Kimia, FKIP Universitas Muhammadiyah Tapanuli Selatan \\ darwis.lubis@um-tapsel.ac.id
}

\begin{abstract}
The problem in this research is the low interest of physics student learning influence to the success of a process of physics learning. To overcome this problem, this research applied learning cycle model (Learning Cycle "5E"). This study aims to improve students' learning creativity, student learning activities, teachers' ability to manage learning and students' interest in physical learning through learning cycle model (Learning Cycle "5E") on Cubes and Balok subjects in class VIII-2 SMP Negeri 4 Angkola Timur. Data analysis shows that for the cycle I there is increase cycle II. The result of observation of student activity on cycle I obtained by cycle II increase. Observation on the ability of teachers to manage to learn in cycle I am in the category of "good," and for cycle II there is an increase that is in the category of "very good". The above conclusions suggest that the implementation of the learning cycle model (Learning Cycle "5E") can be used in an effort to increase the students' learning interest in physics and to the teacher, it is expected to implement the learning cycle model (Learning Cycle "5E") on other subjects on physics lessons or appropriate subjects.
\end{abstract}

Keywords: Student Learning Interest, Learning Cycle Model "5e".

\begin{abstract}
Abstrak
Masalah dalam penelitian ini adalah rendahnya minat belajar fisika siswa berpengaruh terhadap keberhasilan suatu proses pembelajaran fisika. Untuk mengatasi masalah tersebut, pada penelitian ini diterapkan model pembelajaran siklus (Learning Cycle " $5 E$ "). Penelitian ini bertujuan untuk meningkatkan kreativitas belajar fisikasiswa, aktivitas belajar siswa, kemampuan guru mengelola pembelajaran dan minat siswa terhadap pembelajaran fisikamelalui model pembelajaran siklus (Learning Cycle " $5 E$ ") pada pokok bahasan Kubus dan Balok di kelas VIII-2 SMP Negeri 4 Angkola Timur. Analisis data menunjukkan untuk siklus I ada kenaikan siklus II. Hasil observasi aktivitas siswa pada siklus I diperoleh kenaikan siklus II. Observasi terhadap kemampuan guru mengelola pembelajaran pada siklus I berada pada kategori "baik" dan untuk siklus II terjadi peningkatan yaitu berada pada kategori "sangat baik". Kesimpulan di atas maka penelitian ini menyarankan penerapan model pembelajaran siklus (Learning Cycle " $5 E$ ") dapat digunakan dalam upaya meningkatkan minat belajar fisikasiswa dan kepada guru, diharapkan mengimplementasikan model pembelajaran siklus (Learning Cycle " $5 E$ ") pada pokok bahasan lain pada pelajaran fisika atau pada mata pelajaran yang sesuai.
\end{abstract}

Kata kunci: Minat Belajar Siswa, Model Learning Cycle"5e”.

PeTeKa (Jurnal Penelitian Tindakan Kelas dan Pengembangan Pembelajaran) | 138 
PeTeKa (Jurnal Penelitian Tindakan Kelas dan Pengembangan Pembelajaran)

Vol 1 No 2 Tahun 2018 Hal 138-146

\section{PENDAHULUAN}

Pada hakikatnya manusia adalah makhluk yang belajar. Pertama, ia adalah makhluk yang berada dalam proses menjadi (to be). Kedua, ia adalah makhluk yang berada di dalam dunia tetapi tidak terikat pada dunia. Hakikatnya belajar merupakan suatu proses yang ditandai dengan adanya perubahan diri seseorang. Perubahan dari suatu hasil dari proses belajar seperti berubah pengetahuan, pemahaman, sikap dan tingkah laku, percakapan, keterampilan dan kemampuan, serta perubahan aspekaspek yang lain yang ada pada individu yang belajar. Hal yang telah dikemukakan di atas dapat dipandang sebagai titik-titik yang dapat dipakai sebagai titik berangkat dalam merumuskan defenisi belajar. Merumuskan defenisi mengenai belajar yang memadai bukanlah suatu pekerjaan yang mudah. Karena itulah maka defenisi yang kita jumpai adalah banyak sekali mungkin sebanyak ahli yang merumuskannya.

Di bawah ini dikemukakan beberapa defenisi yang dapat dipakai sebagai data mencari inti persoalan. Gulo (2008) menyatakan bahwa "belajar adalah perubahan tingkah laku sebagai hasil pengalaman atau usaha untuk mencari ilmu pengetahuan". Kemudian Hamalik (2007) berpendapat "belajar adalah modifikasi atau memperteguh kelakuan melalui pengalaman (learning is defined as the modification or strengthening of though experiencing)', Sedangkan menurut Slameto (2003) menyatakan "belajar adalah proses usaha yang telah dilakukan individu untuk memperoleh suatu perubahan tingkah laku yang baru secara keseluruhan, sebagai hasil pengalamannya sendiri dalam interaksi dengan lingkungannya'.
Fisika merupakan pelajaran yang diajarkan disetiap jenjang pendidikan. Fisika dipelajari oleh semua siswa SD, SMP, SMA bahkan sampai ke Perguruan Tinggi. Salah satu alasan mengapa fisika perlu diajarkan disetiap jenjang pendidikan karena fisika merupakan mata pelajaran pendukung bagi mata pelajaran lainnya. didefenisikan dengan cermat, jelas dan akurat representasinya. Menurut Jhonson dalam Abdurrahman (2009) menyatakan bahwa "fisika bahasa simbolis yang berfungsi praktisnya untuk mengekpresikan hubunganhubungan kuantitatif dan keruangan sedangkan fungsinya teoritisnya adalah untuk memudahkan berfikir'.

Minat adalah rasa lebih suka dan rasa keterikatan pada suatu hal atau aktifitas, tanpa ada yang menyuruh. Minat pada dasarnya adalah penerimaan akan suatu hubungan antara diri sendiri dengan sesuatu diluar diri. Semakin kuat atau dekat hubungan tersebut, semakin besar minatnya. Minat dapat diekspresikan melalui pernyataan yang menunjukkan bahwa siswa lebih menyukai suatu hal dari pada hal lainnya, dapat pula dimanifestasikan melalui pertisipasi dalam suatu aktifitas. Minat tidak dibawa sejak lahir, melainkan diperoleh kemudian. Minat yang telah disadari terhadap bidang pelajaran, mungkin sekali akan menjaga pikiran siswa, sehingga dia bisa menguasai pelajarannya.

Menurut Djaali (2011) Dapat disimpulkan bahwa minat memiliki unsur afeksi, kesadaran sampai pilihan nilai, pengerahan perasaan, seleksi, dan kecenderungan hati. Minat dapat dibagi ke dalam enam jenis, yaitu (1) realistis, (2) investigatif, (3) artistik, (4) sosial, (5) enterprising, dan (6) konvensional. Bila siswa menyadari bahwa belajar merupakan suatu alat untuk mencapai beberapa tujuan yang dianggap penting 
dan bila siswa melihat bahwa hasil dari pengalaman belajarnya akan membawa kemajuan pada dirinya, kemungkinan besar ia akan berminat (dan bermotivasi) untuk mempelajarinya.

Model pembelajaran siklus merupakan Model pembelajaran yang dapat meningkatkan pengembangan konsep yaitu bagaimana pengetahuan ini dibangun dalam pikiran siswa, dan keterampilan siswa dalam menemukan pengetahuan secara bermakna serta mengingatkan antara pengetahuan lama dengan pengetahuan baru.

$$
\text { Menurut Wena }
$$

menyatakan "Model pembelajaran siklus merupakan salah satu Model pembelajaran yang mengacu pada teori konstruktivisme'. Salma (2008), menyatakan bahwa: "Konstruktivisme adalah aliran yang mengembangkan pandangan tentang belajar yang menekankan pada empat komponen kunci yaitu: (1) siswa membangun pemahaman sendiri dari hasil belajar mereka bukan karena disampaikan pada mereka. (2) pelajaran baru sangat bergantung pada pelajaran sebelumnya. (3) belajar dapat ditingkatkan dengan interaksi sosial. (4) penugasan penugasan dalam belajar dapat meningkat". Tiga tahap siklus tersebut saat ini mengembangkan menjadi lima tahap yang terdiri dari atas tahap : 1) pembangkitan minat (engagement), 2) eksplorasi (eksplonation), 3) penjelasan (explation), 4) elaborasi (elaboration), 5) evaluasi (evaluation).

Tipe ini menuntut siswa untuk memiliki kemampuan yang baik dalam berkomunikasi maupun dalam proses kelompok. Digunakan Model pembelajaran dijelaskan bertujuan agar materi pelajaran yang disampaikan guru akan mudah difahami dan dimengerti oleh siswa dan sehingga dapat diaplikasikan oleh siswa dimasa depannya, di samping itu mampu mengembangkan cara belajar siswa secara aktif sehingga dapat membangkitkan minat siswa. Berdasarkan penjelasan di atas maka (Learning Cycle "5E") sebagai metode yang digunakan guru merupakan upaya untuk mencapai tujuan model pembelajaran fisika khususnya pada kelas VIII SMP Negeri 1 Panyabungan serta terjadinya peningkatan konsep Materi GLB oleh siswa sehingga minat belajar fisika siswa meningkat. Sesuai dengan hasil diskusi dengan guru mata pelajaran fisika kelas VIII disepakati untuk melaksanakan tindakan model pembelajaran dengan menggunakan Model pembelajaran siklus sehingga tujuan model pembelajaran dapat dicapai secara maksimal, yaitu peningkatan minat belajar pada Materi GLB.

\section{METODE}

Jenis penelitian ini adalah penelitian tindakan kelas (Classroom Action Research) yang bertujuan memperbaiki kualitas proses dan hasil pembelajaran fisika terkait peningkatan minat belajar fisika siswa melalui model pembelajaran siklus (Learning Cycle " $5 E$ "). Subjek dalam penelitian tindakan kelas ini adalah siswa kelas VIII-2 SMP Negeri 1 Panyabungan Tahun Pelajaran 2017/ 2018. Objek penelitian ini adalah kemampuan guru dalam mengelola model pembelajaran dan minat siswa dalam pelaksanaan model pembelajaran di kelas dengan upaya meningkatkan minat belajar fisika siswa dengan menggunakan model pembelajaran siklus (Learning Cycle" 5E").

Penelitian ini digunakan jenis PTK (Classroom Action Research). Rancangan penelitian ini dilakukan dengan memberi materi perlakuan terhadap siswa, yaitu dengan model 
PeTeKa (Jurnal Penelitian Tindakan Kelas dan Pengembangan Pembelajaran)

Vol 1 No 2 Tahun 2018 Hal 138-146

pembelajaran siklus (Learning Cycle"5E”). Tahap pelaksanaan tindakan kelas antara lain:1) Perencanaan; 2) Pelaksanaan; 3) Observasi; 4) Refleksi. Melakukan refleksi terhadap pelaksanaan dan menganalisis serta membuat kesimpulan atas pelaksanaan pembelajaran yang telah direncanakan dengan melaksanakan tindakan tertentu. Hal ini meningkatkan minat belajar dengan tes hasil belajar sampai mencapai $80 \%$ dari seluruh siswa.

Teknik pengumpulan data yaitu 1) Lembar Tes: Instrumen tes digunakan mengumpul data yang sifatnya mengevaluasi hasil suatu proses. Tes terdiri dari soal berbentuk esai yang disusun berdasarkan isi materi bangun ruang sisi datar GLB. Sebelum tes dilaksanakan, terlebih dahulu dilakukan teknik analisis data dilakukan pengujian validitas dan reabilitas; 2) Observasi, hal yang diamati adalah aktifitas selama pembelajaran. Teknik ini menuntut adanya pengamatan dari baik secara langsung maupun tidak langsung terhadap objek penelitian. Instrumen yang digunakan adalah lembar pengamatan atau observasi. Tujuan observasi aktivitas siswa adalah untuk melihat aktivitas proses pembelajaran yang berlangsung di kelas; 3) Pengamatan guru: Untuk memperoleh data tentang kemampuan guru dalam mengelola pembelajaran, digunakan instrument berupa lembar penilaian terhadap pengelolaan pembelajaran dengan menggunakan perangkat pembelajaran yang berorientasi pada pendekatan motivasi. Pengamatan, pengamat menuliskan kategori-kategori skor yang muncul dengan menggunakan penilaian terdiri dari 4 kriteria yaitu, tidak baik (nilai 1), kurang baik (nilai 2), cukup baik (nilai 3), baik (nilai 4), sangat baik (nilai 5); 4) Angket adalah angket respon siswa diberikan kepada siswa dan diisi setelah pembelajaran yang meliputi perasaan senang/ tidak senang dan pendapat siswa baru/ tidak baru terhadap komponen materi pelajaran, cara belajar dan cara guru mengajar serta pendapat siswa tentang LKS.

\section{HASIL DAN PEMBAHASAN}

\section{Hasil Tes Belajar Siswa Siklus I}

Pelaksanaan tindakan sikus I merupakan implementasi dari persiapan atau perencanaan yang disusun sebelumnya. Tindakan pada siklus ini merupakan usaha untuk meningkatkan hasil belajar fisika siswa. Selain itu tindakan ini juga berusaha untuk menjadikan proses pembelajaran fisika siswa berlangsung secara efektif. Secara kuantitaif, tingkat hasil belajar siswa dapat dilihat pada tabel 1 .

\section{Tabel1: Deskripsi Nilai Hasil Instrumen Tes Hasil Belajar Pada Siklus I}

\begin{tabular}{|c|c|c|c|}
\hline Nilai & $\begin{array}{c}\text { Jumlah } \\
\text { Siswa } \\
(\text { Orang) }\end{array}$ & $\begin{array}{c}\text { Persen } \\
\text { tase }\end{array}$ & Kategori \\
\hline $90-100$ & 1 & $2,7 \%$ & $\begin{array}{c}\text { Sangat } \\
\text { Baik }\end{array}$ \\
\hline $80-89$ & 9 & $24,3 \%$ & Baik \\
\hline $65-79$ & 15 & $40,5 \%$ & $\begin{array}{c}\text { Cukup } \\
\text { Baik }\end{array}$ \\
\hline $55-64$ & 7 & $19,1 \%$ & Kurang \\
\hline $0-54$ & 5 & $13,5 \%$ & $\begin{array}{c}\text { Sangat } \\
\text { Kurang }\end{array}$ \\
\hline Total & $\mathbf{3 7}$ & $\mathbf{1 0 0 \%}$ & \\
\hline
\end{tabular}

Untuk lebih jelasnya dapat dicermati diagram batang di bawah ini yang menggambarkan tingkat hasil belajar siswa pada siklus I sebagai berikut: 
Darwis, dkk. Upaya Meningkatkan Minat Belajar Fisika Dengan ...

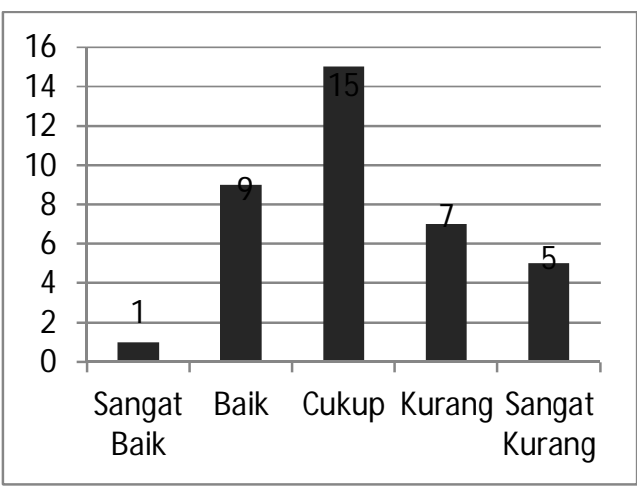

Gambar 1: Tes Hasil Belajar Fisika Siswa Siklus I

Berdasarkan gambar 1 untuk kategori "sangat baik, baik, dan cukup" diharapkan adanya peningkatan jumlah siswa yang signifikan pada siklus berikutnya. Sedangkan untuk kategori penilaian "kurang dan sangat kurang'dilakukan upaya semaksimal mungkin untuk menekan jumlah siswa, sehingga terjasi penurunan.

\section{Hasil Observasi Aktivitas Siswa}

Pengamatan atau observasi merupakan bagian proses dari pengumpulan data yang diperlukan dalam penelitian. Guru yang bertindak sebagai kolabolator mengamati guru yang bertindak sebagai guru PTK yang sedang mengajar di kelas dengan pokok bahasanGLB. Pelaksanaan dilakukan pada saat guru melaksanakan proses pembelajaran dengan model pembelajaran siklus (Learning Cycle " $5 E$ ") untuk meningkatkan minat belajar fisika siswa. Observer memiliki peran mengamati dan mendokumentasikan semua aktivitas siswa yang terjadi dikelas ketika tindakan dilakukan.

Adapun hasil pengamatan observer terhadap aktivitas siswa dalam pembelajaran selama 4 kali pertemuan dapat dilihat pada tabel 2 .
Tabel2: Kadar Aktivitas Siswa Siklus I

\begin{tabular}{|c|c|c|c|c|c|}
\hline \multirow{2}{*}{$\begin{array}{c}\text { Kategori } \\
\text { aspek yang } \\
\text { dinilai }\end{array}$} & \multicolumn{4}{|c|}{$\begin{array}{c}\text { Kadar aktivitas siswa } \\
\text { per pertemuan }\end{array}$} & \multirow[t]{2}{*}{$\begin{array}{l}\text { Rata- } \\
\text { rata }\end{array}$} \\
\hline & I & II & III & IV & \\
\hline Persentase & 50.83 & 63,33 & 369,17 & 72,50 & 63,96 \\
\hline $\begin{array}{l}\text { Kualifikasi } \\
\text { Nilai }\end{array}$ & \multicolumn{5}{|c|}{ Kurang } \\
\hline
\end{tabular}

Kategori tersebut siswa masih malu berdiskusi atau bertanya kepada guru/ teman sehingga nilai yang diperoleh masih kurang baik. Secara keseluruhan pencapaian aktivitas siswa pada siklus I. Terlihat kadar aktivitas aktif siswa untuk 4 (empat) kategori yang seharusnya dipenuhi ternyata belum dipenuhi. Selanjut ditinjau dari segi kadar aktivitas aktif siswa setelah merujuk keefektifan aktivitas seperti yang direncanakan dalam penelitian ini maka disimpulkan bahwa penelitian ini akan dilanjutkan pada siklus II.

\section{Hasil Respon Siswa Terhadap Pembelajaran}

Angket diisi oleh siswa setelah kegiatan pembelajaran selesai yang bertujuan untuk mengetahui pendapat siswa terhadap pembelajaran yang sedang berlangsung. Jumlah siswa yang mengisi angket respon siswa adalah 37 orang. Proporsi jawaban siswa terhadap masing-masing komponen pembelajaran yang disajikan dalam tabel 3:

Tabel3: Respon Siswa Terhadap Kegiatan Pembelajaran Siklus I

\begin{tabular}{|l|l|c|}
\hline No & $\begin{array}{l}\text { Indikator/Aspek } \\
\text { yang Diamati }\end{array}$ & Persentase \\
\hline Rata-rata & $\mathbf{9 5 , 9 4}$ \\
\hline Total rata-rata & $\mathbf{9 4 , 0 9}$ \\
\hline
\end{tabular}

Berdasarkan kriteria pencapaian fektivitas yang diterapkan yaitu respon siswa dikatakan positif apabila rata-rata 
PeTeKa (Jurnal Penelitian Tindakan Kelas dan Pengembangan Pembelajaran)

Vol 1 No 2 Tahun 2018 Hal 138-146

persentase keseluruhan komponen respon siswa lebih besar atau sama dengan $80 \%$. Dari uraian di atas maka respon siswa terhadap pembelajaran siklus (Learning Cycle " $5 E$ ") telah memenuhi kriteria keefektifan.

\section{Hasil Refleksi Siklus I}

Analisis terhadap observasi dijadikan sebagai bahan untuk menentukan tindakan selanjutnya. Setelah diadakan refleksi antara guru, observer dan peneliti maka diperoleh hal-hal sebagai berikut:

\section{Faktor Siswa}

1) Sebahagian besar siswa kurang memperhatikan penjelasan guru

2) Sebahagian siswa kurang aktif dalam mengikuti materi ajar dan siswa belum dapat menyampaikan pendapatnya pada saat materi pelajaran diajarkan atau pada saat siswa mengalami kesulitan dalam menyelesaikan soal-soal dalam LKS, hal ini disebabkan karena siswa merasa asing dengan model pembelajaran siklus (Learning Cycle “5E”).

\section{a. Hasil Tes Hasil Belajar Siswa Secara Kuantitatif.}

Ditinjau dari segi belajar fisika siswa, masih ada siswa tidak dapat menyelesaikan soal secara benar terkait dengan kreativitas siswa. Banyak siswa yang menuliskan jawaban dengan benar sebanyak 17 siswa dari 37 siswa mengikuti tes atau 45,9\%. Untuk memperbaiki kelemahan dan mempertahankan keberhasilan yang telah dicapai pada siklus pertama, maka pada pelaksanaan siklus kedua dapat dibuat perencanaan sebagai berikut:

1) Lebih meningkatkan minat siswa dalam kegiatan belajar mengajar.

2) Memberikan stimulasi kepada siswa agar lebih aktif dalam kegiatan belajar mengajar atau mempersentasikan hasil kelompok.

3) Merespon kegiatan siswa dalam pembelajaran agar kekurangankekurangan yang terjadi pada siklus yang telah lalu dapat diatasi.

\section{b. Aktivitas Siswa Secara Kuantitatif}

Sementara hasil perhitungan persentase aktivitas siswa siklus I, terlihat bahwa rata-rata persentase aktivitas siswa untuk kategori pengamatan "Membaca dan memahami soal LKS, "Menulis (menyelesaikan masalah/ mempersentasekan hasil kerja rangkuman/ kesimpulan/ hal-hal yang penting), "Menyampaikan pendapat/ ide kepada guru/ teman" dan "Berdiskusi/ bertanya kepada guru atau teman", Membaca (buku yang relevan/ membaca LKS" serta kadar aktivitas aktif siswa hanya mencapai $63,96 \%$.

\section{c. Respon Siswa Secara Kuantitatif}

Selanjutnya untuk hasil respon siswa terhadap pembelajaran yang telah berlangsung dan komponen pembelajaran telah terlihat bahwa respon siswa sangat positif, hal ini dibuktikan dari hasil angket respon siswa sebesar 94,09\%. Maka untuk tindakan lanjutan kegiatan pembelajaran supaya dipertahankan maupun ditingkatkan sehingga respon siswa selalu positif.

\section{d. Minat Siswa Secara Kuantitatif}

Selanjutnya untuk hasil minat siswa terhadap pembelajaran yang telah berlangsung dan komponen pembelajaran telah terlihat bahwa minat siswa mulai baik, hal ini dibuktikan dari hasil angket minat siswa sebesar $57,29 \%$. Maka untuk tindakan lanjutan kegiatan pembelajaran supaya dipertahankan maupun ditingkatkan sehingga minat siswa mulai baik. 
Hasil Tes Belajar Siswa Siklus II

Pelaksanaan tindakan siklus II merupakan lanjutan kegitan dar siklus I. Tindakan pada siklus ini adalah usaha untuk meningkatkan minat belajar fisika siswa. Selain itu, tindakan ini juga berusaha untuk menjadikan proses pembelajaran berlangsung secara efektif. Secara kuantitatif, tingkat minat siswa pada tes hasil belajar pada siklus II dapat dilihat pada tabel berikut ini.

\section{Tabel4: Deskripsi Nilai Hasil Instrumen Tes Hasil Belajar Pada Siklus II}

\begin{tabular}{|c|c|c|c|}
\hline Nilai & $\begin{array}{c}\text { Jumlah } \\
\text { Siswa } \\
\text { (Orang) }\end{array}$ & $\begin{array}{c}\text { Persen } \\
\text { tase }\end{array}$ & Kategori \\
\hline $90-100$ & 5 & $13,5 \%$ & $\begin{array}{c}\text { Sangat } \\
\text { Baik }\end{array}$ \\
\hline $80-89$ & 13 & $35,1 \%$ & Baik \\
\hline $65-79$ & 12 & $32,4 \%$ & $\begin{array}{c}\text { Cukup } \\
\text { Baik }\end{array}$ \\
\hline $55-64$ & 7 & $19,1 \%$ & Kurang \\
\hline $0-54$ & 0 & $0 \%$ & $\begin{array}{c}\text { Sangat } \\
\text { Kurang }\end{array}$ \\
\hline Total & $\mathbf{3 7}$ & $\mathbf{1 0 0 \%}$ & \\
\hline
\end{tabular}

Untuk lebih jelasnya dapat dicermati diagram batang di bawah ini yang menggambarkan tingkat hasil belajar siswa pada siklus II sebagai berikut:

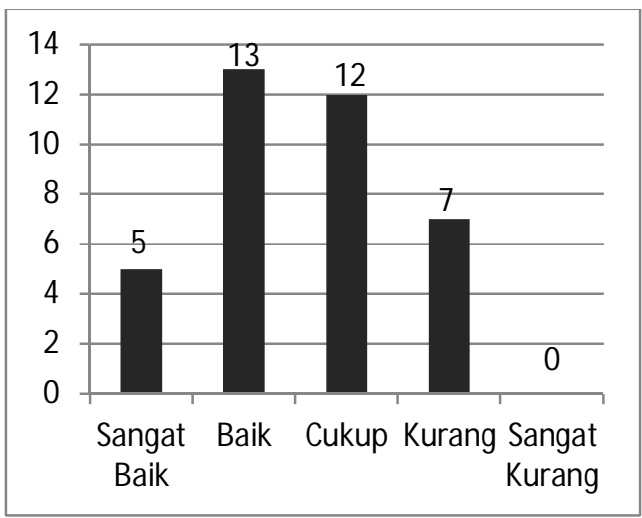

Gambar 2: Tes Hasil Belajar Fisika Siswa Siklus II
Berdasarkan gambar 2 pada kategori "kurang" dan "sangat kurang" terjadi penurunan dibandingkan hasil tes belajar siswa siklus I. Dimana pada kategori "sangat kurang" pada siklus I berjumlah 5 orang siswa dan pada siklus II menurun menjadi 0 orang siswa yang berada pada kategori sangat kurang.

Hasil pengamatan terhadap aktivitas siswa dalam pembelajaran selama 4 kali pertemuan pada siklus II ini dapat dilihat pada tabel 5 .

Tabel5: Kadar Aktivitas Siswa Siklus II

\begin{tabular}{|l|c|c|c|c|c|}
\hline \multirow{2}{*}{$\begin{array}{c}\text { Kategori } \\
\text { aspek yang } \\
\text { dinilai }\end{array}$} & \multicolumn{3}{|c|}{$\begin{array}{c}\text { Kadar aktivitas siswa } \\
\text { per pertemuan }\end{array}$} & \multirow{2}{*}{$\begin{array}{c}\text { Rata- } \\
\text { rata }\end{array}$} \\
\cline { 2 - 4 } & I & II & III & IV & \\
\hline Persentase & 78.80 & 84,10 & 85,80 & 90,00 & 84,71 \\
\hline $\begin{array}{l}\text { Kualifikasi } \\
\text { Nilai }\end{array}$ & \multicolumn{4}{|c|}{ Baik } \\
\hline
\end{tabular}

Dari hasil tersebut dapat disimpulkan bahwa siswa sudah terbiasa dengan model pembelajaran siklus (Learning Cycle “5E”) dan dapat kita lihat sebagian dari aspek penilaian telah mengalami peningkatan dari siklus sebelumnya. Secara keseluruhan pencapaian aktivitas siswa pada siklus kedua.

\section{Hasil Respon Siswa Terhadap Pembelajaran}

Angket diisi oleh siswa setelah kegiatan pembelajaran selesai yang bertujuan untuk mengetahui pendapat siswa terhadap pembelajaran yang sedang berlangsung. Jumlah siswa yang mengisi angket respon siswa adalah 37 orang. Proporsi jawaban siswa terhadap masing-masing komponen pembelajaran disajikan dalam tabel 6 . 
PeTeKa (Jurnal Penelitian Tindakan Kelas dan Pengembangan Pembelajaran)

Vol 1 No 2 Tahun 2018 Hal 138-146

Tabel6: Respon Siswa Terhadap Kegiatan Pembelajaran Siklus II

\begin{tabular}{|l|l|c|}
\hline No & $\begin{array}{l}\text { Indikator/Aspek } \\
\text { yang Diamati }\end{array}$ & Persentase \\
\hline Rata-rata & $\mathbf{9 8 , 6 5}$ \\
\hline Total rata-rata & $\mathbf{9 5 , 6 1}$ \\
\hline
\end{tabular}

Hasil Refleksi Siklus II

\section{a. Hasil Belajar Siswa Secara Kuantitatif}

Ditinjau dari segi hasil tes belajar siswa, siswa sudah bisa menyelesaikan soal secara benar terkait dengan hasil belajar siswa. Hal ini diketahui dari ragam pola jawaban siswa, yang dikelompokkan kedalam 3 (tiga) kategori yaitu: 1) hasil jawaban benar dan mengikuti langkah-langkah lembar kunci jawaban; 2) hasil jawaban salah dan tidak mengikuti langkahlangkah lembar kunci jawaban dan 3) hasil jawaban kosong. Dari pola jawaban di atas secara umum siswa telah mampu menyelesaikan soal dengan benar. Antusias siswa dalam mengerjakan soal telah terlihat sesuai dengan pola jawaban di atas. Banyak siswa yang menuliskan jawaban dengan benar sebanyak 13 siswa dari 37 siswa mengikuti tes atau $40,63 \%$.

\section{b. Aktivitas Siswa Secara Kuantitatif}

Jika ditinjau dari segi aktivitas pada siklus II ini, kadar aktivitas siswa lebih baik dari siklus I. Hal ini terlihat dari kadar aktif siswa seperti: "Membaca dan memahami soal LKS, "Menulis (menyelesaikan masalah/ mempersentasekan hasil kerja rangkuman/ kesimpulan/ hal-hal yang penting), "Menyampaikan pendapat/ ide kepada guru/ teman" dan "Berdiskusi/ bertanya kepada guru atau teman", Membaca (buku yang relevan/ membaca LKS" telah berada dalam batas toleransi yang ditentukan dan kadar aktivitas aktif siswa sebesar $84,71 \%$. Sedangkan kadar aktivitas aktif siswa yang direncanakan dalaam penelitian ini adalah $\geq 80 \%$ dari ratarata kategori aktivitas point a, b, c, d dan e. Dari uraian di atas, jika ditinjau dari segi kadar aktivitas aktif siswa yang telah terpenuhi maka penelitian berhenti pada siklus II.

\section{c. Kemampuan Guru Mengelola Pembelajaran}

Jika ditinjau dari kemampuan guru mengelola pembelajaran siklus (Learning Cycle "5E") pada siklus II lebih baik dari siklus I. Ini terlihat pada hal:

a. Kemampuan mengarahkan siswa untuk menemukan jawaban dan cara menjawab soal, dengan memberikan bantuan terbatas.

b. Kemampuan memimpin diskusi kelas/ menguasai kelas

c. Kemampuan mengelola waktu. Jadi melalui hasil observasi kemampuan guru mengelola pembelajaran untuk tiap pertemuan pada siklus II termasuk pada kategori "sangat baik". Sehingga jika ditinjau dari segi kemampuan guru mengelola pembelajaran sudah terpenuhi maka penelitian ini berhenti pada siklus II.

\section{d. Respon Siswa Secara Kuantitatif}

Dari hasil angket respon siswa pada siklus II ini menunjukkan adanya peningkatan yang positif, dimana hasil respon siswa sebesar 95,61\%. Maka dengan merujuk pada indikator respon siswa dikatakn positif apabila rata-rata persentase keseluruhan komponen respon siswa lebih besar atau sama dengan $80 \%$ untuk kategori senang, baru dan bermina. Maka jika ditinjau dari segi respon siswa terhadap pembelajaran dan komponen pembelajaran telah terpenuhi maka penelitian ini berhenti pada siklus II. 
Darwis, dkk. Upaya Meningkatkan Minat Belajar Fisika Dengan ...

\section{SIMPULAN}

Berdasarkan hasil dan temuan selama pelaksanaan ditinjau dari segi hasil tes belajar siswa, siswa sudah bisa menyelesaikan soal secara benar terkait dengan hasil belajar siswa. Hal ini diketahui dari ragam pola jawaban siswa, yang dikelompokkan kedalam 3 (tiga) kategori yaitu: 1) hasil jawaban benar dan mengikuti langkah-langkah lembar kunci jawaban; 2) hasil jawaban salah dan tidak mengikuti langkahlangkah lembar kunci jawaban dan 3) hasil jawaban kosong. Dari pola jawaban di atas secara umum siswa telah mampu menyelesaikan soal dengan benar. Antusias siswa dalam mengerjakan soal telah terlihat sesuai dengan pola jawaban di atas. Banyak siswa yang menuliskan jawaban dengan benar sebanyak 13 siswa dari 37 siswa mengikuti tes atau $40,63 \%$.

Dari hasil angket respon siswa pada siklus II ini menunjukkan adanya peningkatan yang positif, dimana hasil respon siswa sebesar 95,61\%. Maka dengan merujuk pada indikator respon siswa dikatakn positif apabila rata-rata persentase keseluruhan komponen respon siswa lebih besar atau sama dengan $80 \%$ untuk kategori senang, baru dan bermina. Maka jika ditinjau dari segi respon siswa terhadap pembelajaran dan komponen pembelajaran telah terpenuhi maka penelitian ini berhenti pada siklus II.

\section{DAFTAR PUSTAKA}

Abdurrahman. 2009. Pendidikan Bagi Anak Berkesulitan Belajar. Jakarta: Rineka Cipta.

Djaali. 2011. Psikologo Pendidikan. Jakarta: Bumi Aksara.

Gulo, W. 2008. Strategi belajar mengajar. Jakarta : Grasindo.

Hamalik, Oemar. 2004. Perencanaan Pengajaran Berdasarkan Pendekatan Sistem. Jakarta: Bumi Aksara.

Salma, Prawiradilaja, Dewi. 2008. Prinsip Desain Pembelajaran. Jakarta : PT Raja Grafindo Persada.

Slameto. 2003. Belajar dan Faktorfaktor Yang Mempengaruhinya. Jakarta: Rineka Cipta.

Wena, M. 2010. Strategi pembelajaran inovatif kontemporer (Suatu Tinjauan Konseptual Operasional). Jakarta : Bumi Aksara. 